\title{
Invasion of the dinoflagellate Ceratium furcoides (Levander) Langhans 1925 at tropical reservoir and its relation to environmental variables
}

\author{
Lidiane Cristina da Silva ${ }^{1,6}$, Isabela Carnielli Leone ${ }^{2}$, Maria José dos Santos-Wisniewski, \\ Alberto Carvalho Peret ${ }^{4} \&$ Odete Rocha ${ }^{5}$ \\ ${ }^{1}$ Post-graduate Program in Ecology and Natural Resources, Department of Ecology and Evolutionary \\ Biology, Federal University of São Carlos - UFSCar, Rod. Washington Luís, Km 235, \\ CP 676, CEP 13565-905, São Carlos, SP, Brazil \\ ${ }^{2}$ Laboratory of Bioecology and Crustacean Systematics, Faculty of Philosophy, Sciences and Letters of \\ Ribeirão Preto, University of São Paulo - USP, Av. Bandeirantes, 3900, Bairro Monte Alegre, \\ CEP 14040-901, Ribeirão Preto, SP, Brasil \\ ${ }^{3}$ Institute of Natural Sciences, Federal University of Alfenas - UNIFAL, Rua Gabriel Monteiro da Silva, \\ 714, CEP 37130-000, Alfenas, MG, Brazil \\ ${ }^{4}$ Department of Hydrobiology, Federal University of São Carlos - UFSCar, Rod. Washington Luís, Km 235, \\ CP 676, CEP 13565-905, São Carlos, SP, Brazil \\ ${ }^{5}$ Department of Ecology and Evolutionary Biology, Federal University of São Carlos - UFSCar, \\ Rod. Washington Luís, Km 235, CP 676, CEP 13565-905, São Carlos, SP, Brazil \\ ${ }^{6}$ Corresponding author: Lidiane Cristina da Silva, e-mail: lidianecris2004@yahoo.com.br
}

SILVA, L.C., LEONE, I.C., SANTOS-WISNIEWSKI, M.J., PERET, A.C. \& ROCHA, O. Invasion of the dinoflagellate Ceratium furcoides (Levander) Langhans 1925 at tropical reservoir and its relation to environmental variables. Biota Neotrop. 12(2): http://www.biotaneotropica.org.br/v12n2/en/ abstract?article+bn019120220112

\begin{abstract}
Dinoflagellates of the genus Ceratium are chiefly marine but there are rare occurrences in freshwater. In this study we analyze the invasion and progressive establishment of Ceratium furcoides, an exotic species, in the Furnas Reservoir. Samples were taken at 36 points in the reservoir, during the months of March, June, September and December, 2007. Measurements of some physical and chemical variables were simultaneously performed at each site. The occurrence of $C$. furcoides was registered at 20 sites, with densities varying between 0.57 and 28,564,913.0 ind. $\mathrm{m}^{-3}$. Blooms of this species were recorded in points which were classified as mesotrophic, coinciding with the places receiving high amounts of untreated domestic sewage. $C$. furcoides density was correlated with temperature, nutrients (nitrate and nitrite) and water electric conductivity. The highest density was recorded in June when temperature was low. The presence of Ceratium furcoides in the reservoir apparently has not yet affected the reservoir water quality or other plankton communities. However, if it becomes fully established it could perhaps become a problem in the reservoir or even to spread out to other reservoirs in Rio Grande basin. Keywords: invasive species, algal blooms, eutrophication, reservoir ecology.
\end{abstract}

SILVA, L.C., LEONE, I.C., SANTOS-WISNIEWSKI, M.J., PERET, A.C. \& ROCHA, O. Invasão do dinoflagelado Ceratium furcoides (Levander) Langhans $1925 \mathrm{em}$ um reservatório tropical e sua relação com as variáveis ambientais. Biota Neotrop. 12(2): http://www.biotaneotropica.org.br/v12n2/pt/ abstract?article+bn019120220112

Resumo: Dinoflagelados do gênero Ceratium são principalmente marinhos, porém existem raras ocorrências em água doce. Neste estudo analisamos a invasão e o estabelecimento progressivo de Ceratium furcoides, uma espécie exótica no reservatório da UHE de Furnas. Foram coletadas amostras em 36 locais em todo o reservatório durante os meses de março, junho, setembro e dezembro de 2007. Variáveis físicas e químicas foram aferidas em cada local. C. furcoides ocorreu em 20 dos 36 pontos de coleta, em densidades que variaram entre 0.57 e 28.564.913 ind. $\mathrm{m}^{-3}$. A maior densidade da espécie foi registrada na região do rio Marimbondo (G14) classificada como mesotrófica e local onde alto volume de esgoto doméstico sem tratamento é lançado diariamente. A densidade de $C$. furcoides foi correlacionada com os valores de temperatura, nutrientes dissolvidos (nitrato e nitrito) e com a condutividade elétrica. Até o momento do presente estudo, a presença de Ceratium furcoides no reservatório aparentemente não afetou as condições ambientais ou outras comunidades, porém, ao se tornar plenamente estabelecida poderá se transformar em um risco ecológico e até mesmo espalhar-se para outras bacias. Palavras-chave: espécie invasora, blooms algais, eutrofização, ecologia de reservatórios. 


\section{Introduction}

The introduction of exotic species into natural habitats is one of the most serious problems facing communities and endemic species, as it can change irreversibly the ecological functioning of the ecosystems involved (Simberloff 1996). The gravest of these would be the local extinction of native species caused chiefly by strong competition and predation (Baskin 1994). The competitive pressure of introduced species and their consumption of members of native populations can modify the local species composition and the longterm effects depend on the particular response of each community (Delariva \& Agostinho 1999).

Freshwater habitats are especially prone to invasion by exotic species, as their dispersion through the natural environment is strongly aided by the flow of water. Aquaculture is nowadays considered one of the main activities by which exotic species have been introduced in many new habitats and countries (Delariva \& Agostinho 1999). Moreover, in aquatic environments usually the introduction of species occurs by microscopic organisms, whose invasions are poorly understood, and its impact on the environment is probably underestimated. The invasion and spread of non-native species of many different kinds of organisms is of increasing interest to researchers (Kastovsky et al. 2010).

Species of this genus Ceratium have been considered invasive in freshwaters of several countries. According to Mac Donagh et al. (2005), surface blooms created by dinoflagellates of the genus have been seen in tropical reservoirs only recently. For this reason, studies on the temporal and spatial dynamics of the species and how this relates to the conditions in tropical systems are still rare. Blooms of these organisms have been reported in some reservoirs, associated with environmental changes such as decreasing nutrient levels and dissolved oxygen concentration. The changes triggered by Ceratium spp. blooms can lead to mass death among fish, as recorded in Thailand and Japan (Taylor et al. 1995), or among invertebrates, as seen in Mexico (Landsberg 2002, Hallengraeff et al. 1995).

Ceratium furcoides was recently recorded for the first time in Brazilian freshwaters at Furnas reservoir in Minas Gerais state by Santos-Wisniewski et al. (2007). After this, a bloom of Ceratium furcoides was reported in the eutrophic Billings Reservoir, São Paulo city, by Matsumura-Tundisi et al. (2010) and the authors suggested that this occurrence was related to the intense process of mixing which might have caused a sharp increase in the phosphorus content in the water column and hence favoring the rapid blooming of this algae.

In this study we investigate the hypothesis that the invasion and establishment of Ceratium furcoides in the Furnas Reservoir is related to the eutrophication, so that its greatest abundances occur in areas with highest concentrations of nutrients.

The main objective of this study was to determine if $C$. furcoides is already fully established in the reservoir and to analyze if its occurrence is related to other changes in reservoir water quality.

\section{Material and Methods}

\section{Study area}

The Furnas reservoir is located in the Rio Grande river basin at the southern part of Minas Gerais State, Brazil. The reservoir extends along parts of the Rio Grande River and several of its tributaries, with a maximum length of $220 \mathrm{~km}$, total perimeter $3,500 \mathrm{~km}$, flooded area $1,440 \mathrm{~km}^{2}$, total volume 22.95 billion $\mathrm{m}^{3}$ and a residence time around 160 days. The maximum depth (near the dam) is $90 \mathrm{~m}$ and the average depth $13 \mathrm{~m}$ (Furnas UHE report 2004). This is the largest reservoir in southeast Brazil and consists of two great arms, River Grande and River Sapucai. The dam lies some kilometers downstream of the confluence of the two arms, between the districts of São José da Barra and São João Batista (Del Aguila 2001).

As the reservoir is constituted by two different drainage basins, it has some quite distinctive features. The River Grande drains soils characteristic of a sand stone plateau of infertile land with extensive cattle-raising. By contrast, the Sapucai River drains the water from soils used for intensive agriculture and pasture, especially intensive cultivation of coffee, potatoes, sugarcane, sweet corn, oranges and soya (Pinto-Coelho \& Corgosinho 1998).

Parts of the Furnas reservoir are already undergoing a process of eutrophication, near the districts of Alfenas, Boa Esperança, Carmo do Rio Claro, Fama and Paraguaçu, in which untreated domestic sewage is discharged directly into the water. In the Fama region of the Sapucai compartment, some sites are eutrophic, with excessive growth of cyanobacteria in one of its tributaries, the Machado River (Sá et al. 1996).

\section{Sampling}

Collections were made at three-month intervals, in March, June, September and December, 2007, at 36 sites scattered throughout the Furnas reservoir, including the central body of water and each of the main arms formed in the Grande and Sapucai sub-basins. Up to now this is the first study covering the whole reservoir with such a large number of sampling points. At each site, the plankton was sampled and physical and chemical variables were tested, in both the limnetic and littoral zones (Figure 1).

The temperature $\left({ }^{\circ} \mathrm{C}\right)$ and dissolved oxygen concentration $(\mathrm{mg} / \mathrm{L})$ in the water were measured in situ up and down the water column, each half meter, by means of a Yellow Springs YSI 30 analog thermistor-oxymeter. The electrical conductivity was measured with a Field conductivity meter (Cole Parmer 19820-10) and the $\mathrm{pH}$ with a field $\mathrm{pH}$-meter (Cole Parmer 59002-00). Nutrient concentrations and chlorophyll- $a$ concentrations were determined in the surface, middle and bottom layer. The techniques described by Mackereth et al. (1978) (total N, nitrate and nitrite) and Golterman et al. (1978) (total P and ortophosphate) were followed. Reactive silicate was analyzed by the method described in Golterman et al. (1978). The chlorophyll- $a$ concentration was estimated by acetone extraction, employing the technique described by Lorenzen (1967). Transparency (m) of the water was determined with a Secchi disk.

Carlson's trophic state index (TSI), modified by Toledo et al. (1983), was calculated from the observed total P, chlorophyll- $a$ and Secchi disk results. The trophic state was classified on the following basis: oligotrophic for TSI $<44$; mesotrophic for TSI $=44-54$; eutrophic for TSI $>54$.

Vertical hauls in the entire water column using plankton net of 68 $\mu \mathrm{m}$ mesh size were carried out to collect plankton in the entire water column. Samples were fixed in $4 \%$ formaldehyde solution and stored in polyethylene flasks. The species were checked for taxonomical identification under high magnification microscope of the Zeiss ${ }^{\circledR}$.

The Ceratium furcoides was identified according to SantosWisniewski et al. (2007). It is a member of the family Ceratiaceae and Class Dinophyceae and morphologically close to the species Ceratium hirundinella (D.F. Müller) Dujardin 1841 in many characteristics. The main difference between the two species is related to the number of the apical plates. $C$. hirundinella has 4 apical plates reaching the apex while in $C$. furcoides 3 apical plates reaches the apex and the $4^{\text {th }}$ does not reach the apex (Santos-Wisniewski et al. 2007). Additionaly in $C$. furcoides the epivalve is conical whereas in C. hirundinella it is elm shaped.

Numerical density of Ceratium furcoides organisms were determined by counting $1 \mathrm{~mL}$ aliquots of the fixed samples in 
a Sedgwick-Rafter counting cell under light microscope at x50 magnification.

Environmental variables measured were analyzed by principal component analysis in order to express the importance of each variable. The relationships between $C$. furcoides densities and environmental parameters were analyzed by Canonical Correspondence Analysis, both performed with the also CANOCO statistical package (Ter Braak 1986). The overall variability of variables among the sampling points was evaluated by estimating the coefficient of variation $(\mathrm{CV})$ by the formula: $\mathrm{CV}=$ standard deviation/average.

\section{Results}

The distribution of Ceratium furcoides over the 36 sampling sites in the Furnas reservoir varied appreciably during the study year (Figure 2). In March, June and December, the dinoflagellate was identified at 15 sites and in September, at 16. At two locations, G16 and G17, it was identified in March, but not at any other time. At 3 sites on the Rio Grande (G1, G4 and G10), C. furcoides was not recorded in March, but was found from June onwards. At S15, the species was recorded from September, while at S16, it appeared only in December. During the entire study, C. furcoides was observed at 20 of the 36 sites, only 3 of these (S15 - 17) being located in the Sapucai River arm, 2 in the central body (G1 and G2) and the rest (G3 - 17) in the Rio Grande arm. Among the sites G1 (at the dam) to G15, there was a noticeable tendency for the density of this species to increase with increasing distance from the dam (Figure 3). Over the whole period, the highest densities of $C$. furcoides were recorded in samples taken at G14, a location known to receive a constant discharge of untreated domestic sewage (Figure 2).

Densities of $C$. furcoides varied greatly among sampling sites and in short periods of time. Although a very low value was recorded in the first sampling $\left(0.57 \mathrm{ind} / \mathrm{m}^{3}\right)$, it subsequently changed to the maximum of $28,564,913 \mathrm{ind} / \mathrm{m}^{3}$, in the next monthly sampling (Figure 2).

In addition to the high densities of $C$. furcoides at G14, high values for total nitrogen, total phosphorus and chlorophyll- $a$ were also recorded. In general there were no great changes in the values measured in each sampling site. However there is heterogeneity in the values of these variables, which were sampled throughout the water column, indicating that the reservoir is a complex system and dependent on the dam that provides events such as opening and closing of gates, and the existence of different compartments, including lotic, transitional and lentic areas (Table 1 and 2).

Practically all the collecting sites in the Furnas reservoir were oligotrophic, exceptions being S1, G18 and G19, where the water became mesotrophic in December, and G14, which was found to be mesotrophic in June and September and eutrophic in December. In March the whole reservoir was oligotrophic, and the highest density of $C$. furcoides occurred at point G14, but there was a steady rise in the TSI throughout the year, from March to December (Figure 3).

The first two components of the Principal Component Analysis explained $42.0 \%$ of the total variability for the environmental variables measured in Furnas Reservoir (Figure 4). It can be observed

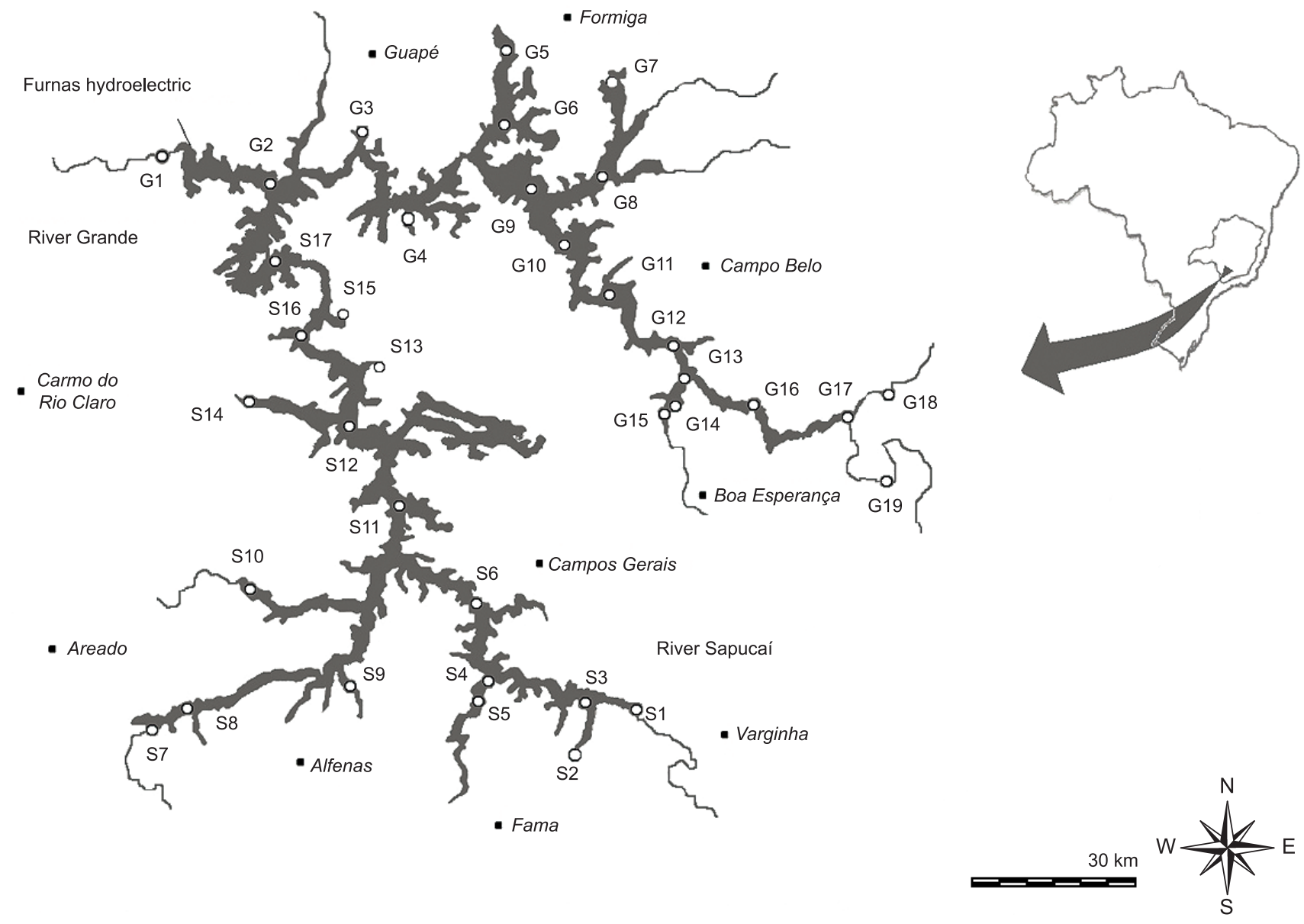

Figure 1. Map of Furnas reservoir showing the location of the 36 sampling sites; Rio Sapucai sub-basin (S1 to S17) on the left, and Rio Grande sub-basin (G1 to G19) on the right. 
Silva, L.C. et al.

M



J



D

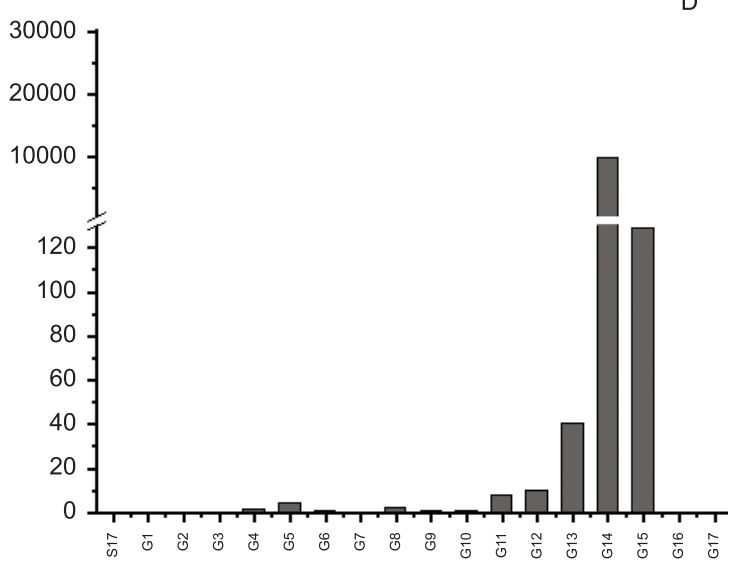

Figure 2. Ceratium furcoides mean density $\left(\mathrm{ind} / \mathrm{m}^{3}\right.$ ) at each site in the Furnas reservoir, recorded from March to December 2007.

Table 1. Mean values and standard deviations of physical and chemical variables at the main portions of Furnas Reservoir, MG, recorded in March, June, September and December, 2007.

\begin{tabular}{|c|c|c|c|c|c|c|}
\hline & $\begin{array}{c}\text { Temperature } \\
\left({ }^{\circ} \mathbf{C}\right) \\
\end{array}$ & $\begin{array}{c}\text { Dissolved } \\
\text { Oxygen }(\mathrm{mg} / \mathrm{L})\end{array}$ & $\begin{array}{c}\text { Conductivity } \\
(\mu \mathrm{S} / \mathrm{cm})\end{array}$ & pH & $\begin{array}{c}\text { Chlorophyll- } a \\
(\mathrm{mg} / \mathrm{L})\end{array}$ & $\begin{array}{c}\text { Tranparency } \\
(\mathbf{m})\end{array}$ \\
\hline $\begin{array}{l}\text { Lower Portion of River } \\
\text { Sapucaí arm }\end{array}$ & $23.5 \pm 3.0$ & $6.26 \pm 0.7$ & $39.05 \pm 4.0$ & $7.55 \pm 0.3$ & $2.73 \pm 1.5$ & $2.48 \pm 1.4$ \\
\hline $\begin{array}{l}\text { Middle Portion of River } \\
\text { Sapucaí arm }\end{array}$ & $23.72 \pm 3.0$ & $5.46 \pm 1.5$ & $42.50 \pm 5.40$ & $7.52 \pm 0.6$ & $3.70 \pm 1.3$ & $2.28 \pm 0,9$ \\
\hline $\begin{array}{l}\text { Upper Portion of River } \\
\text { Sapucaí arm }\end{array}$ & $24.16 \pm 24.1$ & $6.40 \pm 1.4$ & $35.9 \pm 4,8$ & $7.66 \pm 0.6$ & $3.25 \pm 1.2$ & $2.74 \pm 1.3$ \\
\hline $\begin{array}{l}\text { Lower Portion of River } \\
\text { Grande arm }\end{array}$ & $22.97 \pm 1.8$ & $5.65 \pm 1.1$ & $33.37 \pm 3.5$ & $7.40 \pm 0.3$ & $0.70 \pm 0.4$ & $3.28 \pm 1.1$ \\
\hline $\begin{array}{l}\text { Middle Portion of River } \\
\text { Grande arm }\end{array}$ & $24.23 \pm 2.0$ & $6.42 \pm 1.1$ & $34.96 \pm 2.46$ & $7.51 \pm 0.34$ & $1.15 \pm 0.4$ & $2.73 \pm 0.9$ \\
\hline $\begin{array}{l}\text { Upper Portion of River } \\
\text { Grande arm }\end{array}$ & $23.85 \pm 3.1$ & $6.61 \pm 1.2$ & $42.41 \pm 4.30$ & $7.74 \pm 0.37$ & $18.21 \pm 10.2$ & $1.60 \pm 0.6$ \\
\hline
\end{tabular}

that the temperature, IET, and the concentrations of total phosphorus, orthophosphate, nitrite, nitrate and dissolved oxygen were the most representative compared to the others as total nitrogen, chlorophyll- $a$, $\mathrm{pH}$ and water electrical conductivity. The sampling points located in the Rio Grande $(\mathrm{G})$ portion of the Furnas Reservoir were mainly related to the values of temperature, chlorophyll- $a$, IET, total nitrogen, total phosphorus, nitrite, orthophosphate and water conductivity. On the other hand, the sampling points located in the Rio Sapucaí (S) portion were related to the variables $\mathrm{pH}$, nitrate and dissolved oxygen.

The Canonical Correspondence Analysis (CCA) associating Ceratium furcoides densities to the environmental variables had $97.3 \%$ of the total variability explained by the first two axes. 
Population density values were mainly associated with point G14. The variable water temperature in December was also associated with this point in Rio Grande and to the values of $C$. furcatus density in March. The point G15, where densities of $C$. furcoides were high was also associated with variables indicative of increasing trophic state as the concentrations of nitrite and nitrate and water conductivity in different months along the year of study (Figure 5).

As a whole the highest densities of $C$. furcoides were positively related to water temperature and conductivity and to the concentrations of nitrite and nitrate in the Furnas Reservoir.

\section{Discussion}

A wide variation in the abundance of Ceratium furcoides across space and time was noted in the samples taken from all parts of the Furnas reservoir, over a period of one year. In spite of the rather favorable growth conditions detected at most of the sites sampled in this study, the great heterogeneity of the chemical and physical variables recorded in the reservoir, could be responsible for the observed variation in the population densities. This was evidenced by wide range variation for each variable (except $\mathrm{pH}$ ) shown by variation coefficients ranging from $44 \%$ to $156 \%$. This heterogeneity of the environmental variables is common in the Furnas reservoir due to its large extension and also by the large inflow of water from many tributaries throughout its area (Table 3 ).

The recorded density of this reached a peak of 28,564 ind $\mathrm{L}^{-1}$ in the Marimbondo River a tributary of the Rio Grande River (site G14). This site is next to a constant discharge of untreated domestic sewage and this is likely to be the main cause of proliferation of this dinoflagellate in the reservoir. At the same site, high concentrations of chlorophyll- $a$ were recorded, peaking at $169.2 \mu \mathrm{g} \mathrm{L}^{-1}$ in December. Besides the dinoflagellate bloom itself, these high concentrations of chlorophyll are also due to blooms of other algae, mainly cyanobacteria.

Some authors have recorded Ceratium blooms in habitats classed as eutrophic. High densities of $C$. hirundinella were recorded in tropical eutrophic water bodies in Argentina (Claps \& Ardohain 2007), Australia (Whittington et al. 2000) and South Africa (Hart 2007). In other studies, however, it has been found that dinoflagellates, including the genus Ceratium, tend to become dominant under mesotrophic conditions (Periotto et al. 2007). It follows that Ceratium furcoides does proliferate successfully in oligotrophic waters, although it reached the highest densities, under mesotrophic conditions whereas bloom-forming cyanobacteria are more often dominant under eutrophic or hypereutrophic.

Table 2. Mean values and standard deviation of nutrient concentrations for the main areas of Furnas Reservoir, MG, recorded in March, June, September and December, 2007.

\begin{tabular}{|c|c|c|c|c|c|c|}
\hline & Total N $(\mu \mathrm{g} / \mathrm{L})$ & Nitrite $(\mu \mathrm{g} / \mathrm{L})$ & Nitrate $(\mu \mathrm{g} / \mathrm{L})$ & Total P $(\mu \mathrm{g} / \mathrm{L})$ & Ortofosfate $(\mu \mathrm{g} / \mathrm{L})$ & Silicate $(\mathrm{mg} / \mathrm{L})$ \\
\hline $\begin{array}{l}\text { Lower Portion of } \\
\text { River Sapucaí arm }\end{array}$ & $597.92 \pm 0.1$ & $6.27 \pm 1.7$ & $230.20 \pm 78.9$ & $45,17 \pm 33.6$ & $12.35 \pm 7.7$ & $3.50 \pm 1.1$ \\
\hline $\begin{array}{l}\text { Middle Portion of } \\
\text { River Sapucaí arm }\end{array}$ & $482.50 \pm 0.1$ & $2.90 \pm 1.0$ & $61.48 \pm 35.6$ & $27.50 \pm 21.2$ & $6.66 \pm 4.5$ & $4.50 \pm 0.8$ \\
\hline $\begin{array}{l}\text { Upper Portion of } \\
\text { River Sapucaí arm }\end{array}$ & $589.33 \pm 0.2$ & $2.15 \pm 0.9$ & $67.97 \pm 28.8$ & $20.12 \pm 14.3$ & $6.56 \pm 3.6$ & $3.33 \pm 0.5$ \\
\hline $\begin{array}{l}\text { Lower Portion of } \\
\text { River Grande arm }\end{array}$ & $491.68 \pm 0.2$ & $2.05 \pm 1.0$ & $153.60 \pm 26.6$ & $21.73 \pm 14.0$ & $4.30 \pm 1.2$ & $3.43 \pm 0.7$ \\
\hline $\begin{array}{l}\text { Middle Portion of } \\
\text { River Grande arm }\end{array}$ & $536.46 \pm 0.1$ & $2.10 \pm 0.9$ & $99.23 \pm 33.7$ & $25.90 \pm 24.1$ & $5.68 \pm 2.31$ & $3.86 \pm 0.7$ \\
\hline $\begin{array}{l}\text { Upper Portion of } \\
\text { River Grande arm }\end{array}$ & $530.36 \pm 0.2$ & $2.91 \pm 1.2$ & $107.90 \pm 58.0$ & $80.07 \pm 97.9$ & $10.51 \pm 5.53$ & $4.56 \pm 1.26$ \\
\hline
\end{tabular}

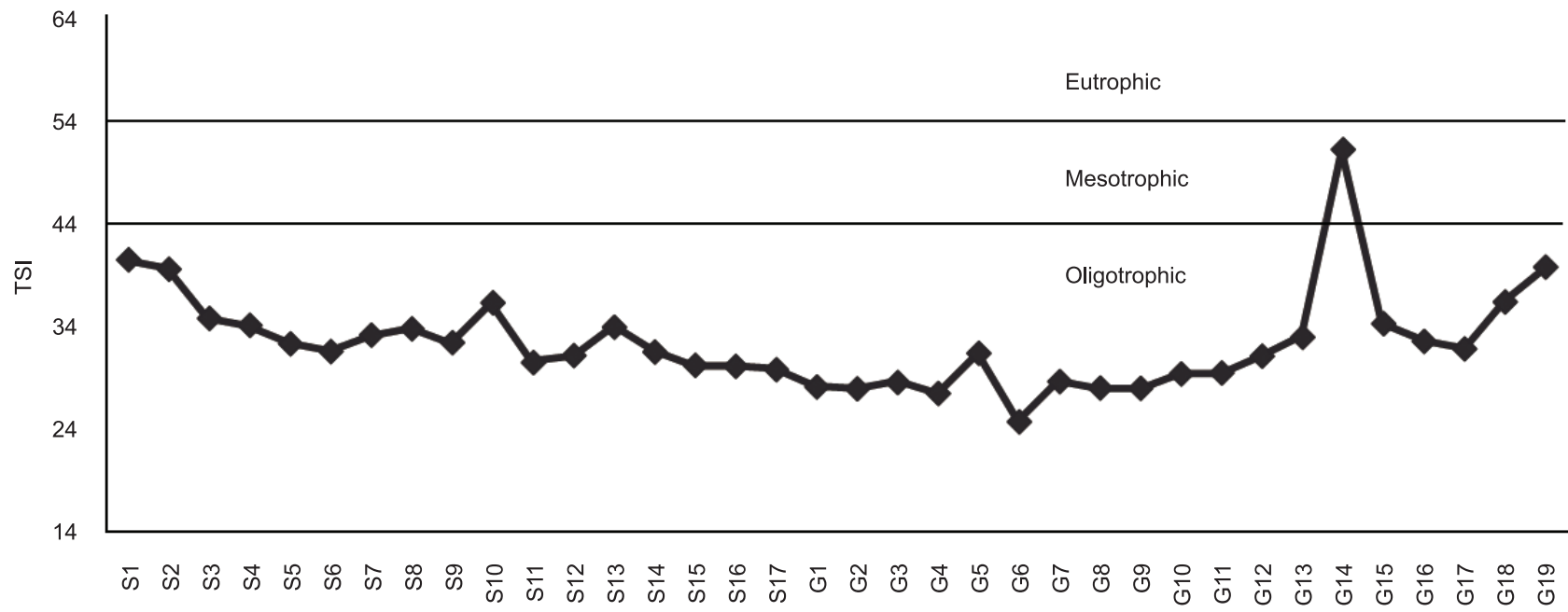

Figure 3. Mean values of trophic state index of Carlson (1971) modified by Toledo et al., (1978) for each sampling site in Furnas reservoir, from March to December 2007. 
The highest densities recorded in Furnas reservoir were in June. In this season, large quantities of nutrients could be due to winter water circulation or external forces. The CCA analysis positively associated the densities of C.furcoides with the highest values of the nutrients nitrate and nitrite.

The highest density of $C$. furcoides recorded in the Furnas reservoir was 28,564 ind $\mathrm{L}^{-1}$ This value is relatively low, compared to many other reservoirs. For example, in the South African subtropical reservoir at Albert Falls, the density of Ceratium species varied from 150 to $1,320,000$ ind $\mathrm{L}^{-1}$ (Hart 2007). A population of various species of Ceratium in an estuary in the Gulf of Nicoya in Costa Rica reached a total density of 4,000,000 ind $\mathrm{L}^{-1}$ (Vargas-Montero \& Freer 2004), while in the eutrophic lake La Quebrada in Argentina, the single species $C$. hirundinella peaked at 32,500,000 ind $\mathrm{L}^{-1}$ (Periotto et al. 2007). It is likely that this difference relates to the fact that the Furnas reservoir is still in oligotrophic and mesotrophic conditions most of the year. However, in the Bilings Reservoir, located in São Paulo state in Brazil, the values $\left(25,000\right.$ ind $\left.\mathrm{L}^{-1}\right)$ registered by MatsumuraTundisi et al. (2010) were close to the values found in this study for the same conditions.

It has been pointed out by Perez-Martınez \& Sanchez-Castillo (2001), in a study of Spanish reservoirs that most of the published field studies on the ecology of $C$. hirundinella have been carried out in temperate zones, where the low temperatures and poor

Table 3. Values of coefficient variation (CV) recorded for environmental variables of Furnas Reservoir, MG, in March, June, September and December, 2007. (Temp. - Temperature; Oxy. - Dissolved Oxygen; Cond. - Conductivity; Chlor. - Chlorophyll- $a$; Tranp. - Transparence; Ortop. - Orthophosfate).

\begin{tabular}{ccccccccccccc}
\hline (\%) & Temp. & Oxy. & Cond. & pH & Chlor. & Transp. & Total N & Nitrite & Nitrate & Total P & Ortop. & Silicate \\
\hline Maximum & 18 & 44 & 58 & 10 & 92 & 71 & 50 & 77 & 100 & 156 & 97 & 47 \\
Minimum & 1 & 3 & 1 & 1 & 10 & 20 & 1 & 0 & 8 & 23 & 19 & 9 \\
\hline
\end{tabular}

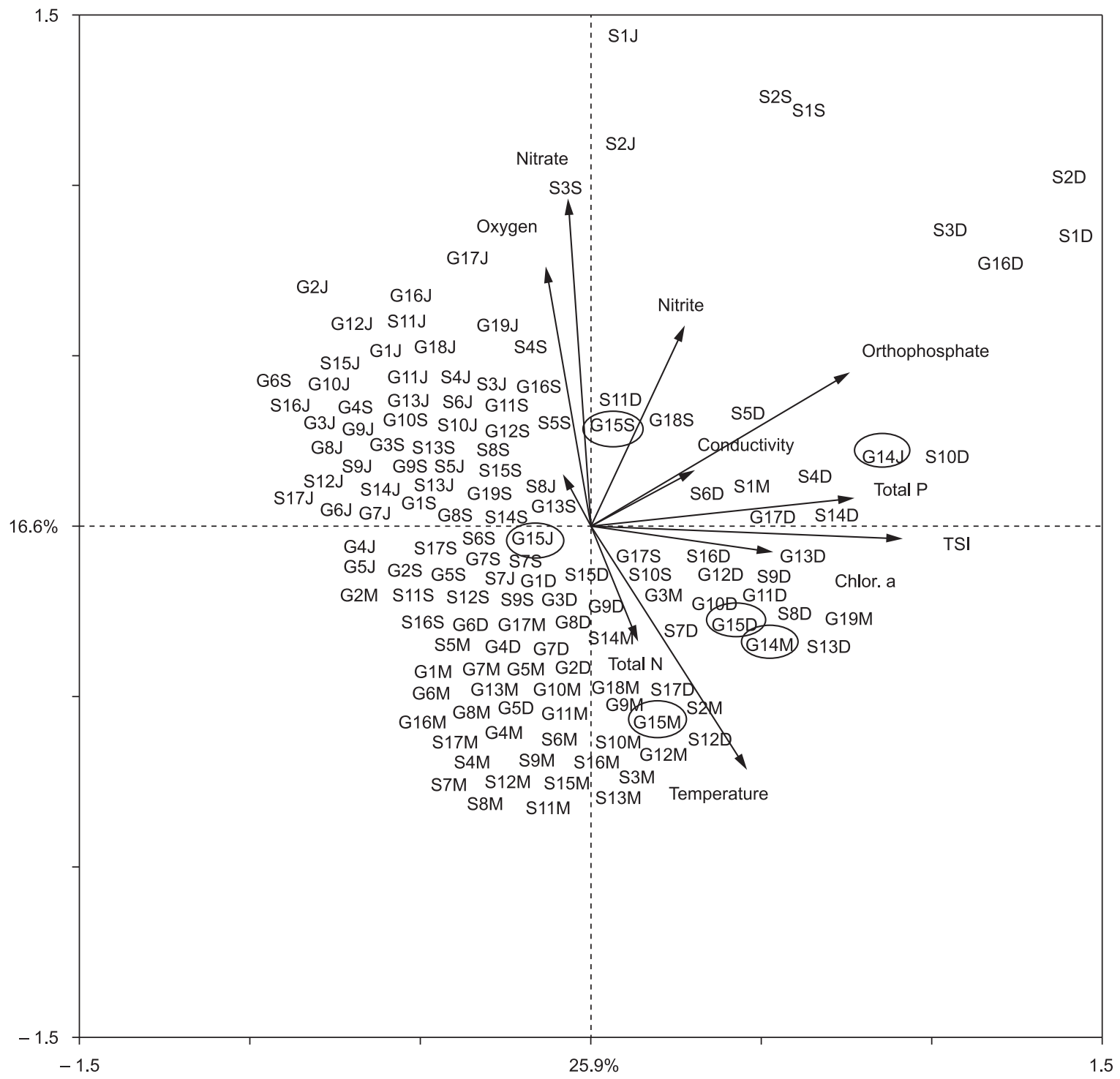

Figure 4. PCA ordination diagram correlating the most significant physical and chemical variables measured in Furnas Reservoir with sampling points and collection months. (M - March; J - June; S - September; D - December). 
illumination that prevail in the winter would probably inhibit its permanence. However, in this study, Ceratium dinoflagellates should frequently be permanent organisms, recorded in all seasons of the year, owing to the warmer temperatures and especially the highly transparent water observed in the cool, dry months In fact, field studies made in regions where such conditions prevail have shown evidence of the development of these dinoflagellates in all seasons around the year, for example in lake La Quebrada in Argentina (Periotto et al. 2007) and Lake Kinneret in Israel (Pollingher \& Hickel 1991). However, despite the occurrence of $C$. furcoides have been ongoing throughout the year, the high densities of C. furcoides were related to the low temperatures recorded in winter in the month of June. Therefore, despite being considered a permanent, C. furcoides better development occurred in conditions with lower temperatures. The canonical correspondence analysis (CCA) showed a significant relationship between $C$. furcoides densities and the water temperature.
Thus the initial hypothesis of this study that C.furcoides invasion and establishment in Furnas reservoir is related to the increase of nutrients (nitrate and nitrite) in some locations was accepted.

So far the presence of Ceratium furcoides in the Furnas reservoir apparently has not yet affected the environmental conditions or other communities, but eventually as it becomes fully established it could turn into a nuisance or spread out to other basins. Watching the effects of Ceratium furcoides invasion in Brazilian freshwaters will be of great relevance presently and in the near future.

\section{Acknowledgements}

To the National Agency of Electrical Energy Research and Development (ANEEL P \& D) and to the Hydrobiology and Fish Farming Research Station of Furnas Hydroelectric Power S.A., for the facilities provided and for providing data of physical and chemical analysis; the Brazilian Research Council-CNPq, for the scholarship to the first author and to T. C. Roberts, for the English translation.

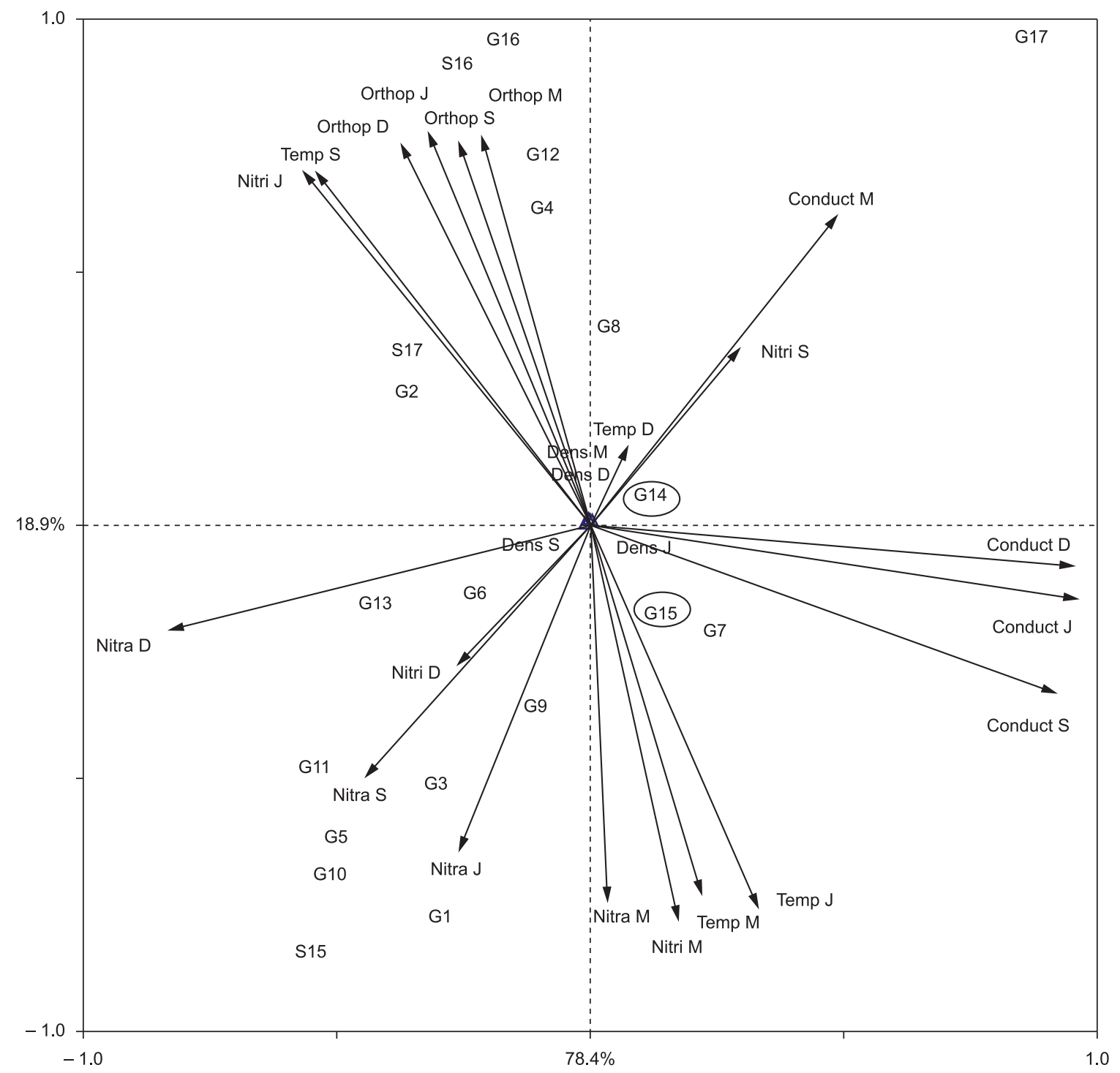

Figure 5. CCA ordination diagram relating the densities (ind. $\mathrm{m}^{-3}$ ) of Ceratium furcoides and environmental variables measured in the Furnas reservoir $(\mathrm{M}$ - March; J - June; S - September; D - December; Nitra = Nitrate; Nitri = Nitrite; Temp = Temperature Conduct = Conductivity; Orthop = Orthophosphate $)$. 


\section{References}

BASKIN, Y. 1994. Ecosystem function of biodiversity. Rev. BioScience 44(10):657-660. http://dx.doi.org/10.2307/1312507

CLAPS, M. \& ARDOHAIN, D. 2007. Zooplankton characterization in a subtropical reservoir (Córdoba, Argentina) during the period 1996-2005. In Plankton Symposium IV. J. Biol. 2:108.

DEL AGUILA, R. 2001. Gradiente trófico no rio Sapucaí (Reservatório de Furnas - MG): Relação com a distribuição do zooplâncton e os usos do solo. Dissertação de mestrado, Universidade Federal de Minas Gerais, Belo Horizonte.

DELARIVA, R.L. \& AGOSTINHO, A.A. 1999. Introdução de espécies: uma síntese comentada. Acta Sci. 21 (2): 255-262.

GOLTERMAN, H.L., CLYMO, R.S. \& OHNSTAD, M.A.M. 1978. Methods for physical and chemical analysis of freshwater. 2nd ed. Blackwell Scientific Publications, Oxford, 213p.

HALLENGRAEFF, G.M., ANDERSEN, D.M. \& CEMBELLA, A.D. 1995. Manual of Harmfull Marine Microalgae. Intergovernmental Oceanographic Commission, UNESCO, 551p.

HART, R.C. 2007. Temporal Dynamics and spatial perspectives of contemporary blooms of the dinoflagellate Ceratium in a subtropical South African Reservoir. In Plankton Symposium IV. J. Biol. 2:159.

KASTOVSKY, J., HAUER, T., MARES, J., KRAUTOVA, M., BESTA, T., KOMAREK, J., DESORTOVA, B., HETESA, J., HINDAKOVA, A., HOUK, V., JANECEK, E., KOPP, R., MARVAN, P., PUMANN, P., SKACELOVA, O. \& ZAPOMELOVA, E. 2010. A review of the alien and expansive species of freshwater cyanobacteria and algae, a case study from the Czech Republic. Biol. Invasions 12(10):3599-3625. http://dx.doi. org/10.1007/s10530-010-9754-3

LANDSBERG, J.H. 2002. The effects of harmfull algae blooms on aquatic organisms. Rev. Fish. Sci. 10(2):113-390.

LORENZEN, C.J. 1967. Determination of chlorophyl and pheo- pigments: Spectrophotometric equations. Limnol. Oceanogr. 12:343-346. http:// dx.doi.org/10.4319/lo.1967.12.2.0343

MAC DONAGH, M.E., CASCO, M.A. \& CLAPS, M.C. 2005. Colonization of a neotropical reservoir (Córdoba, Argentina) by Ceratium hirundinella (O. F. Miiller). Ann. limnol. - Int. J. Lim. 41(4):291-299.

MACKERETH, J.F.H., HERON, J. \& TALLING, J.F. 1978. Water analysis: some revised methods for limnologists. Titus Wilson \& Sons Ltda, Kendal. Freshwater Biological Association, n.36, 121p.

MATSUMURA-TUNDISI, T., TUNDISI, J.G., LUZIA, A.P. \& DEGANI, R.M. 2010. Occurrence of Ceratium furcoides (Levander) Langhans 1925 bloom at the Billings Reservoir, São Paulo State, Brazil. Braz. J. Biol. 70(3):825-829.
PEREZ-MARTINEZ, C. \& SANCHEZ-CASTILLO, P. 2001. Temporal occurrence of Ceratium hirundinella in Spanish reservoirs. Hidrobiology 452:101-107.

PERIOTTO, M., PRÓSPERI, C., DAGA, C. \& RINCÓN, A. 2007. Estudio de Ceratium hirundinella en El Embalse La Quebrada, Córdoba, Argentina. In International Congress on Development Environment and Natural Resources: Multi-level and Multi-scale Sustainability. Cochabamba, Bolívia.

PINTO-COELHO, R.M. \& CORGOSINHO, P.H.C. 1998. Alterações na estrutura do zooplâncton em resposta a um gradiente de trofia no reservatório de Furnas, Minas Gerais. In Seminário de Ecologia. UFSCar, São Carlos, p.1173-1188.

POLLINGHER, U. \& HICKEL, B. 1991. Dinoflagellate associations in a subtropical lake (Lake Kinneret, Israel). Arch. Hydrobiol 120: 267-285.

SÁ, JR., LIMA, M.N., EVANGELISTA, M.A., PERES, S.A. \& GOMES, A.P.G. 1996. Programa de monitoramento limnológico. In Caracterização limnológica do reservatório da Usina Hidroelétrica de Furnas (Furnas). Estação de Hidrobiologia e Piscicultura de Furnas.

SANTOS-WISNIEWSKI, M.J., SILVA, L.C., LEONE, I.C., LAUDARESSILVA, R. \& ROCHA, O. 2007. First Record of the occurrence of Ceratium furcoides (Levander) Langhans 1925, an invasive species in the hydroelectricity power plant Furnas Reservoir, MG, Brazil. Braz. J. Biol. 67(4):791-793.

SIMBERLOFF, D. 1996. Impacts of introduced species in the United States. Rev. Consequences 2(2):13-24.

TAYLOR, F., FUKUYO, Y. \& LARSON, J. 1995. Taxonomy of harmful dinoflagellates. In Manual of harmful marine microalgae (G.M. Hallengraeff, D.M. Andersen \& A.D. Cembella, eds.). Intergovernmental Oceanographic Commission, UNESCO, Paris, 551p.

TER BRAAK, C.J.F. 1986. Canonical correspondence analysis: a new eigenvector technique for multivariate direct gradient analysis. Ecology 67(6):1167-79.

TOLEDO, A.P., TALARICO, M., CHINEZ, S.J. \& AGUDO, E.G. 1983. A aplicação de modelos simplificados para avaliação do processo da eutrofização em lagos e reservatórios tropicais. In Congresso Brasileiro de Engenharia Sanitária e Ambiental. Camboriú, p.1-34.

VARGAS-MONTERO, M. \& FREER, E. 2004. Presence of the dinoflagellates Ceratium dens, $C$. fusus and $C$. furca (Gonyaulacales: Ceratiaceae) in Golfo de Nicoya, Costa Rica. Rev. Biol. Trop. 52(1):115-120.

WHITTINGTON, J., SHERMAN, B., GREEN, D. \& OLIVER, R.L. 2000. Growth of Ceratium hirundinella in a subtropical Australian reservoir: the role of vertical migration. J. Plankton Res. 22(6):1025-1045. 